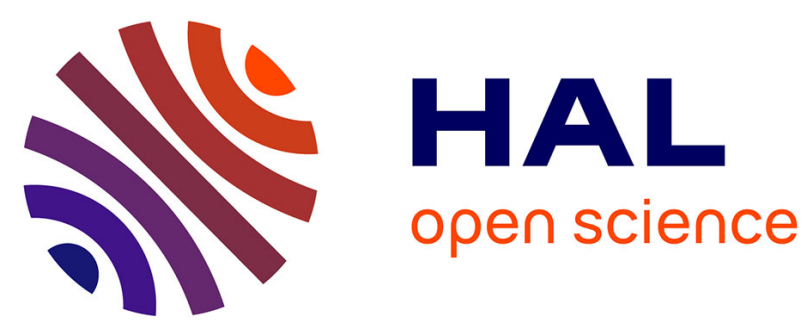

\title{
Pulp capping materials modulate the balance between inflammation and regeneration
}

Thomas Giraud, Charlotte Jeanneau, Charlotte Rombouts, Hengameh Bakhtiar, Patrick Laurent, Imad About

\section{> To cite this version:}

Thomas Giraud, Charlotte Jeanneau, Charlotte Rombouts, Hengameh Bakhtiar, Patrick Laurent, et al.. Pulp capping materials modulate the balance between inflammation and regeneration. Dental Materials, 2019, 35 (1), pp.24-35. 10.1016/j.dental.2018.09.008 . hal-02185271

\section{HAL Id: hal-02185271 \\ https://hal-amu.archives-ouvertes.fr/hal-02185271}

Submitted on 16 Jul 2019

HAL is a multi-disciplinary open access archive for the deposit and dissemination of scientific research documents, whether they are published or not. The documents may come from teaching and research institutions in France or abroad, or from public or private research centers.
L'archive ouverte pluridisciplinaire HAL, est destinée au dépôt et à la diffusion de documents scientifiques de niveau recherche, publiés ou non, émanant des établissements d'enseignement et de recherche français ou étrangers, des laboratoires publics ou privés. 


\title{
Pulp capping materials modulate the balance between inflammation and regeneration
}

\author{
Thomas Giraud $^{a, b}$, Charlotte Jeanneau ${ }^{a}$, Charlotte Rombouts ${ }^{a}$, \\ Hengameh Bakhtiar ${ }^{c}$, Patrick Laurent ${ }^{a, b}$, Imad About ${ }^{a, *}$ \\ a Aix Marseille Univ, CNRS, ISM, Inst Movement Sci, Marseille, France \\ b APHM, Hôpital Timone, Service d'Odontologie, Marseille, 13005, France \\ c Dental Material Research Center, Tehran Dental Branch, Islamic Azad University, Tehran, Iran
}

\section{A R T I C L E I N F O}

\section{Article history:}

Received 20 July 2018

Received in revised form

14 September 2018

Accepted 16 September 2018

\begin{abstract}
A B S T R A C T
The interrelations between inflammation and regeneration are of particular significance within the dental pulp tissue inextensible environment. Recent data have demonstrated the pulp capacity to respond to insults by initiating an inflammatory reaction and dentin pulp regeneration. Different study models have been developed in vitro and in vivo to investigate the initial steps of pulp inflammation and regeneration. These include endothelial cell interaction with inflammatory cells, stem cell interaction with pulp fibroblasts, migration chambers to study cell recruitment and entire human tooth culture model. Using these models, the pulp has been shown to possess an inherent anti-inflammatory potential and a high regeneration capacity in all teeth and at all ages. The same models were used to investigate the effects of tricalcium silicate-based pulp capping materials, which were found to modulate the pulp anti-inflammatory potential and regeneration capacity. Among these, resin-containing materials such as $\mathrm{TheraCal}^{\oplus}$ shift the pulp response towards the inflammatory reaction while altering the regeneration process. On the opposite, resin-free materials such as Biodentine ${ }^{\mathrm{TM}}$ have an anti-inflammatory potential and induce the pulp regeneration capacity. This knowledge contradicts the new tendency of developing resin-based calcium silicate hybrid materials for direct pulp capping. Additionally, it would allow investigating the modulatory effects of newly released pulp capping materials on the balance between tissue inflammation and regeneration. It would also set the basis for developing future capping materials targeting these processes.
\end{abstract}

¡ 2018 The Academy of Dental Materials. Published by Elsevier Inc. All rights reserved.

\footnotetext{
* Corresponding author at: Institut des Sciences du Mouvement (ISM), UMR 7287 CNRS \& Université d'Aix-Marseille, Faculté d'Odontologie, 27 Bd Jean Moulin, MARSEILLE Cedex 5 13385, France.

E-mail addresses: thomas.giraud@univ-amu.fr (T. Giraud), charlotte.jeanneau@univ-amu.fr (C. Jeanneau), romboutscharlotte@gmail.com (C. Rombouts), hengamehbakhtiar@yahoo.com (H. Bakhtiar), patrick.laurent@univ-amu.fr (P. Laurent), imad.about@univ-amu.fr (I. About).

https://doi.org/10.1016/j.dental.2018.09.008

0109-5641/@ 2018 The Academy of Dental Materials. Published by Elsevier Inc. All rights reserved.
} 


\section{Contents}

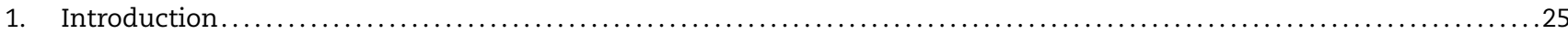

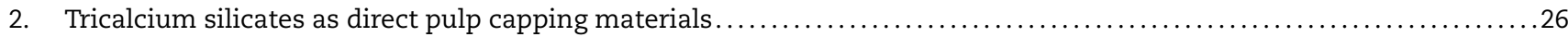

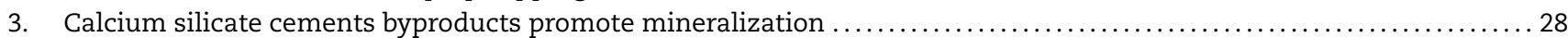

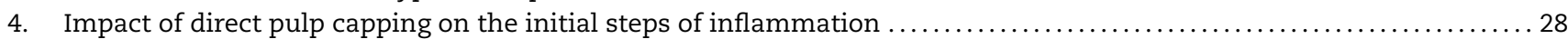

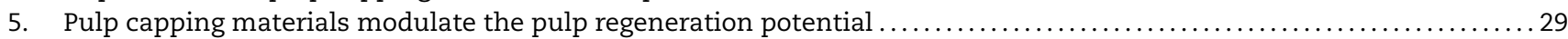

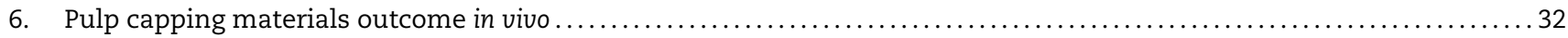

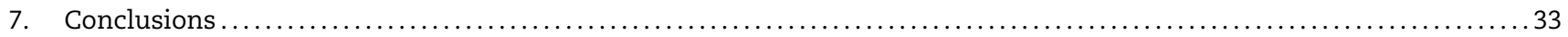

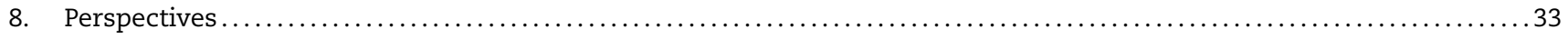

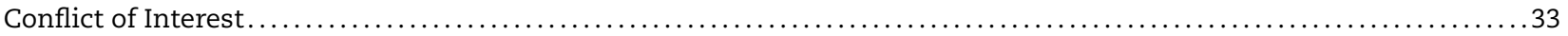

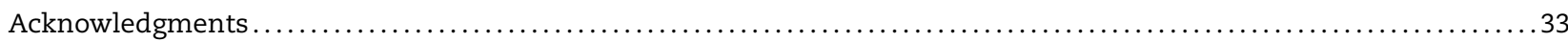

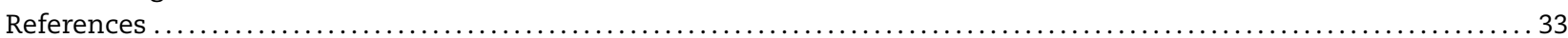

\section{Introduction}

The dental pulp tissue is located within rigid dentinal walls [1]. This unique location in a terminal blood circulation renders this tissue vulnerable unless a local regulation provides protective mechanisms to this particular tissue. In this regard, several lines of evidence suggest that the dental pulp has local regulation mechanisms of its inflammation and regenerative capacity. In a first-line defence, odontoblasts that lie under the dentin barrier and pulp fibroblasts express pattern recognition receptors (PRRs). These include Toll-like receptors (TLRs) $[2,3]$ which are able to detect bacterial invaders by recognizing common molecules on their surface, the pathogen-associated molecular patterns (PAMPs). After this recognition, these cells initiate an inflammatory cascade by activating the NF-kB pathway, essential for the inflammatory response by initiating the production of pro-inflammatory cytokines [4]. These will establish a chemotactic gradient for guiding inflammatory cell migration towards the inflammation site (Fig. 1). During this process, inflammatory cells adhere on the activated vascular endothelium, then migrate through the endothelial cell layer and reach the inflammatory site guided by the proinflammatory cytokines [5]. Then they will be activated into macrophage-like cells at the inflammatory site where they eliminate pathogens and cell debris (Fig. 1).

Besides cytokines, the complement system is another important actor of the inflammatory process. Complement is activated by the classical, alternative, or mannose-binding lectin pathway [6]. Upon pulp tissue damage and/or infection, the Complement provides the signals required for eliminating invading pathogens and altered host cells. Recent data have shown that pulp fibroblasts are the first nonimmune cells capable of producing all components required for Complement activation [7]. Complement activation by pulp fibroblasts leads to the production of inflammatory mediators and recruitment of inflammatory cells by anaphylatoxins such as $\mathrm{C} 5 \mathrm{a}$ and $\mathrm{C} 3 \mathrm{a}$ [8-10]. These anaphylatoxins induce the vascular modifications required to allow inflammatory cells to migrate towards the inflammation site in order to eliminate the infectious agents [11]. Additionally, Complement activation by pulp fibroblasts leads to the formation of the cytolytic membrane attack complex (MAC) [12]. After fixation on cariogenic bacteria, this complex leads to their direct destruction [13]. Thus, Complement activation appears to be essential in initiating the inflammatory reaction and in controlling cariogenic bacteria.

Although inflammation is a prerequisite for healing and regeneration [1] it can also be detrimental if it persists given the fact that the pulp is confined in a rigid environment, leaving no room for swelling [2]. In case of severe inflammation, this may lead to pulp destruction. Additionally, if the infection persists, the resulting chronic inflammation will hamper the regenerative processes and will eventually lead to pulp necrosis.

Besides controlling bacterial progression and inflammation, it is well established that the dental pulp of both primary and permanent teeth, and at all ages, is rich in stem cells [14-16]. In case of traumatic injuries and/or pulp infection, regeneration signals, such as growth factors, induce their proliferation, migration and differentiation to regenerate the dentin-pulp tissue [14] (Fig. 2). Indeed, after stimulation, these dental pulp stem cells (DPSC) migrate to the injury/inflammatory site and differentiate into odontoblast-like cells. Upon differentiation, they express specific markers of odontoblasts such as the intermediate filament Nestin and Dentin SialoProtein (DSP) which is known for its implication in the mineralization process. Indeed, cells expressing Nestin and DSP were seen in contact and within mineralized foci in the dental pulp close to the injury site $[17,18]$.

DPSC recruitment to the injury/inflammation site requires the presence of active molecules to direct their migration. Recent works on Complement activation have demonstrated that pulp fibroblast Complement activation is also involved in dental-pulp regeneration by providing Complement active fragments such as $\mathrm{C} 5 \mathrm{a}$ and $\mathrm{C} 3 \mathrm{a}$. Indeed, it has been shown that DPSC recruitment, is selectively guided by a C5a gradient [19]. Another fragment, C3a, also promotes the regenerative processes by increasing DPSC and pulp fibroblast proliferation, mobilizing DPSC and guiding pulp fibroblast migration to the Complement activation site [20]. This indicates that in addition to its role in initiating the inflammatory reaction, Complement activation by pulp fibroblasts produce the regeneration signals required for the regeneration process particularly in guiding DPSC migration to the injury site. Thus, Complement activation provides the missing link between inflammation and regeneration [21]. 


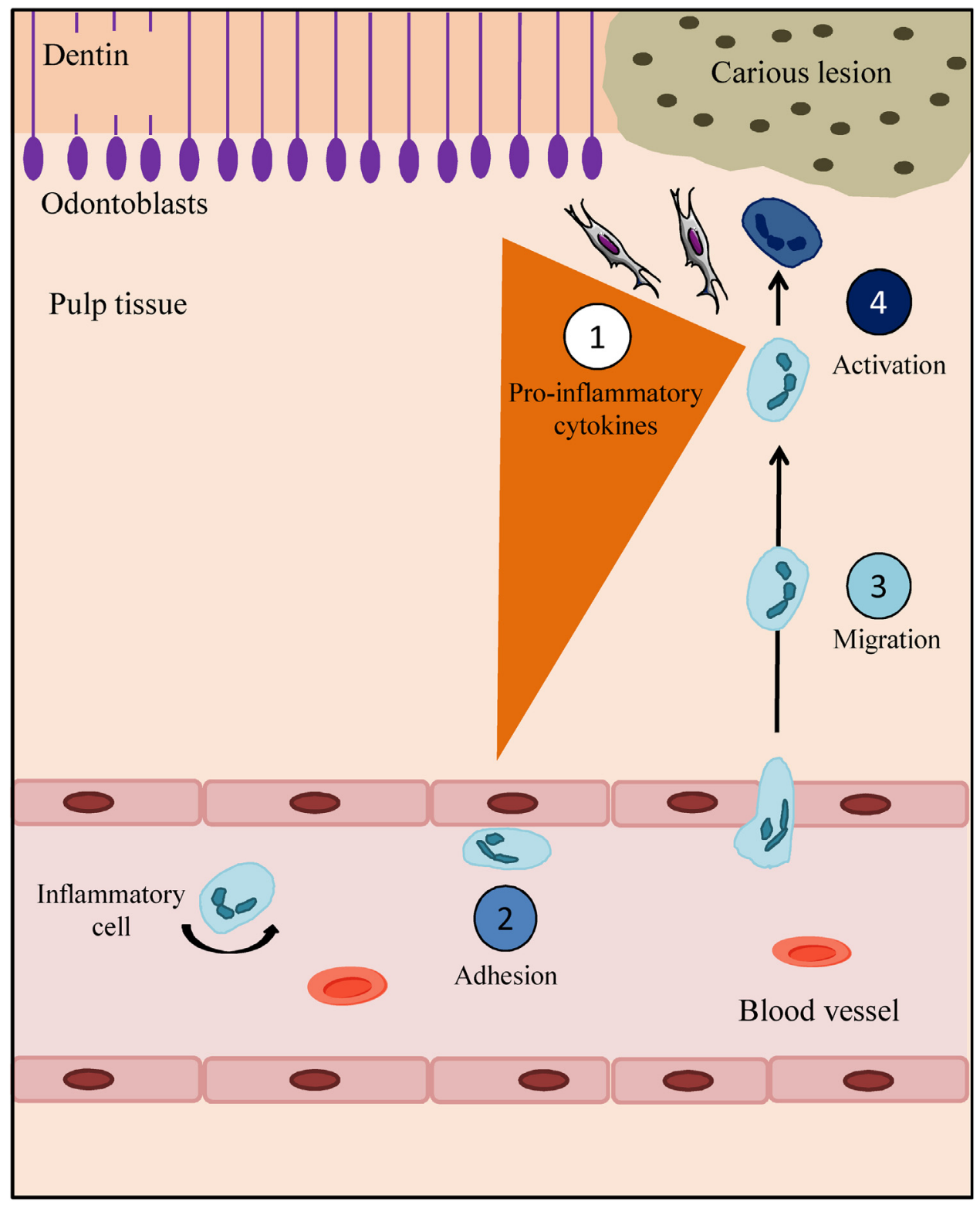

Fig. 1 - Schematic representation of the initial steps of pulp inflammation.

Following a carious lesion, the inflammatory reaction implies secretion of pro-inflammatory cytokines (1) by resident cells, such as pulp fibroblasts. Circulating inflammatory cells adhere on the activated vascular endothelium (2), then migrate and reach the injured site (3) to be finally activated as macrophage-like cells (4).

\section{Tricalcium silicates as direct pulp capping materials}

Calcium-silicate based cements (CSC) have been developed more than 20years ago with Mineral Trioxide Aggregate $\left(\mathrm{MTA}^{\circledR}\right)$ being the most well-known and most widely used formulation [22]. It is a Portland Cement (PC) based formulation containing mainly tricalcium (C3S) and dicalcium silicates (C2S) [23] which sets and develops its properties in the presence of moisture. CSC were initially developed as endodontic repair and root-end filling materials [22-24]. Given their biocompatible properties, their clinical usage rapidly expanded towards direct and indirect pulp capping.
Nevertheless, there are some disadvantages associated with these classic MTA formulations including a long setting time, difficult handling, poor mechanical properties and tooth discoloration [24-26]. Researchers have thus been working to improve CSC's physico-mechanical and handling properties and many new products have been introduced on the market, each having their specific set of components (setting modulators, radiopacifying agents and drugs). However, besides the required physico-mechanical properties, pulp-capping materials should have suitable biological properties given their direct contact with vital pulp tissue.

Taking into consideration the handling and biological properties, two CSC materials have been developed with enhanced mechanical properties: 1.) Biodentine ${ }^{\mathrm{TM}}$ (Septodont, 


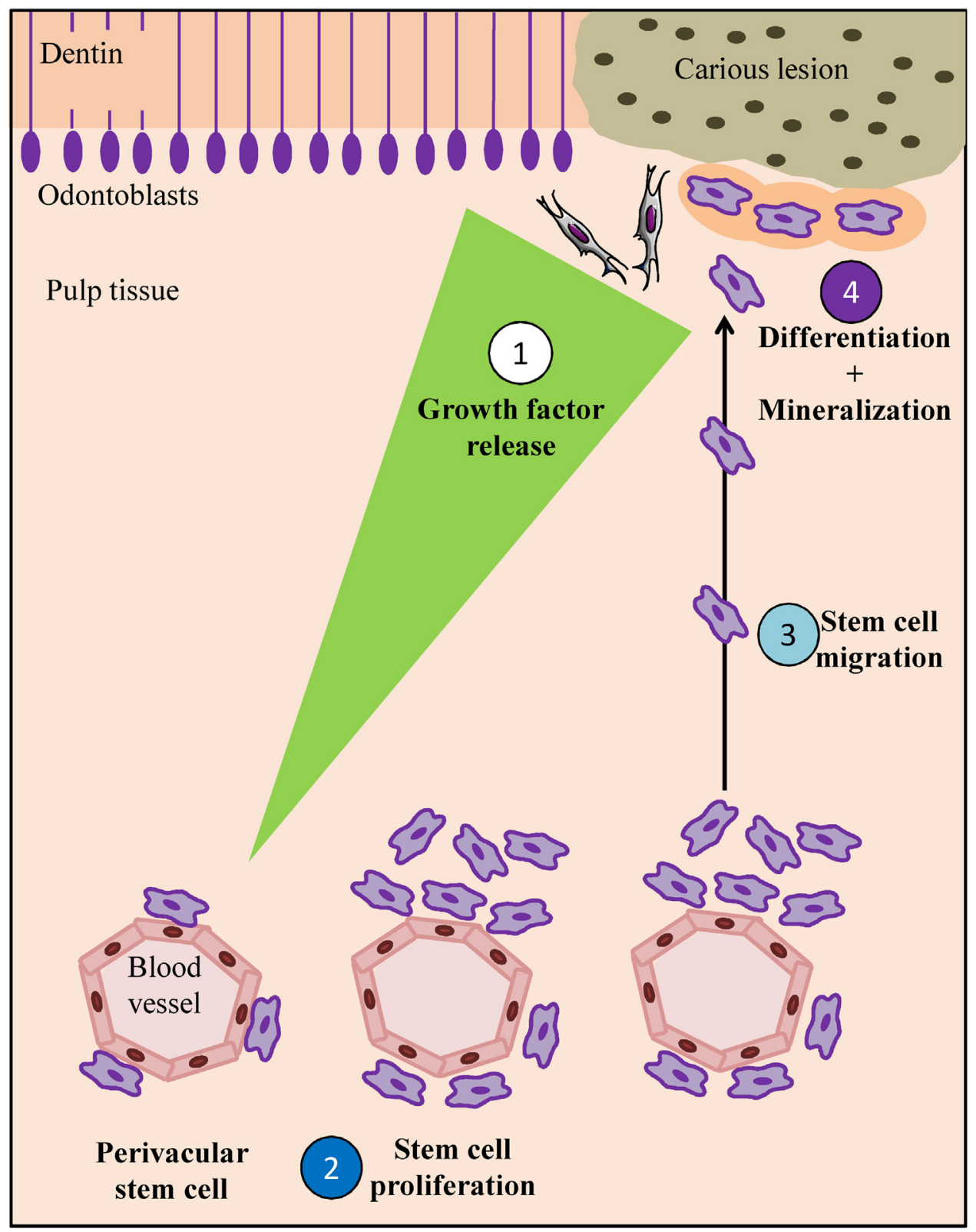

Fig. 2 - Schematic representation of the initial steps of dentin-pulp regeneration.

Following a carious lesion, dental pulp cells such as fibroblasts secrete growth factors (1). These growth factors create a gradient leading to perivascular stem cell proliferation (2) and their migration to the injured site (3). Finally, migrating stem cells differentiate into odontoblasts-like cells and secrete mineralized matrix to protect the pulp tissue (4).

Saint-Maur-des-Fossés, France) is resin-free and mainly composed of pure tricalcium silicates and calcium chloride as a setting accelerator. It is presented as powder and liquid to be prepared by mixing both components with an amalgamator. It sets in 12 min which is much shorter than MTA $^{\circledR}$ that sets after $2 \mathrm{~h} 45 \mathrm{~min}$ [27]. 2.) TheraCal ${ }^{\circledR}$ (Bisco, Schaumburg, IL, USA), is composed of PC and contains $43 \%$ of resins. It is presented as a ready-to-use material in a syringe and sets by photopolymerization ( $20 \mathrm{~s}$ per $1 \mathrm{~mm}$ increment) in a hydrophobic environment. The complete composition of these materials has been reported [28].

Previously published works have already reported that resin-based materials cannot be recommended for direct pulp capping [29]. However, the recent development of resincontaining hybrid materials for direct and indirect pulp capping, stating their improved mechanical and handling properties, raises questions about their consequences to the pulp healing potential. For instance, the byproduct formation from calcium silicate in these hybrid materials on setting is different from those observed in resin-free CSC materials. In addition, the development of these materials represents a risk to the pulp vitality due to the resin components and their potential toxicity.

In this review we will focus on the effect of these two recently developed CSC, the resin-free Biodentine ${ }^{\mathrm{TM}}$ and resin-containing $\mathrm{TheraCal}^{\circledR}$, on the initial steps of two 


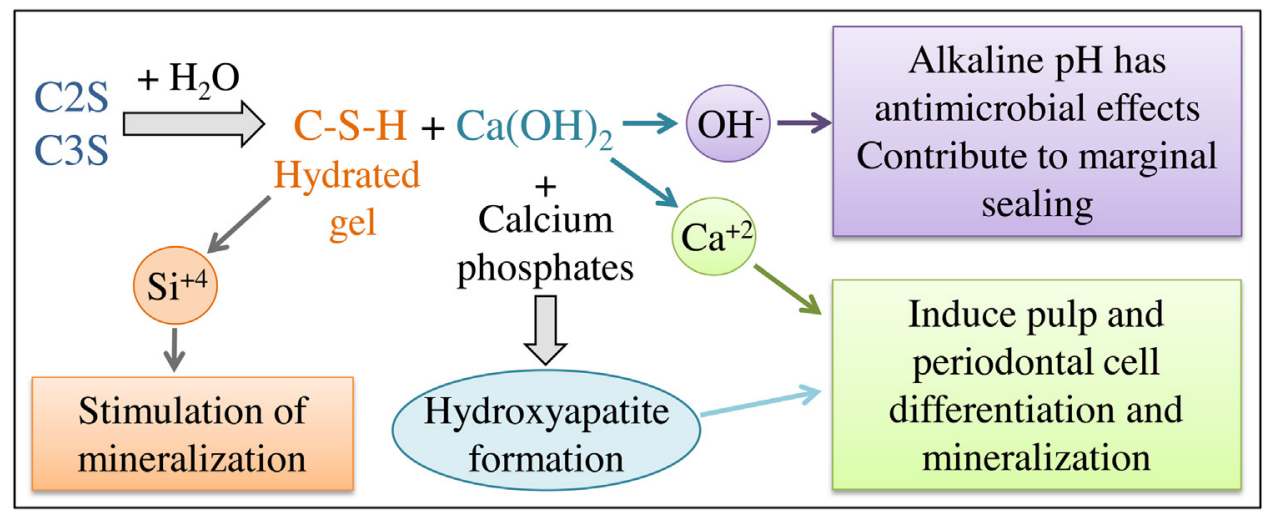

Fig. 3 - Silicate-based material hydration byproducts on setting and their biological effects.

Schematic representation of the setting hydration reaction of silicate-based (C2S: dicalcium silicate, C3S: tricalcium silicates) materials. This reaction leads to byproducts formation: $\mathrm{OH}^{-}, \mathrm{Ca}^{2+}$ and $\mathrm{Si}^{4+}$. The released hydroxyl ions increase the $\mathrm{pH}$ in the underlying tissue leading to anti-microbial effect. Calcium ions are involved in dentin-bridge formation as they stimulate DPSC differentiation. Silicon ions also promote mineralization. Calcium hydroxide induces dentin bridge formation.

crucial biological processes which determine the success/failure of the clinical outcome: inflammation and regeneration.

\section{Calcium silicate cements byproducts promote mineralization}

Calcium silicate setting reaction is hydration. During this reaction, hydration byproducts can form/be released (Fig. 3). Most CSC lead to calcium hydroxide formation, and leaching of hydroxyl ions and calcium ions as demonstrated for MTA ${ }^{\circledR}$ and Biodentine $^{\mathrm{TM}}$, amongst others [30-32]. The released hydroxyl ions upon hydration will increase the $\mathrm{pH}$ in the underlying tissue leading to a thin necrotic layer between the remaining vital tissue and the pulp capping agent $[33,34]$. The presence of this necrotic zone protects the underlying vital pulp cells from the material's alkaline pH. Furthermore, it allows the underlying pulp cells to carry out the healing and regeneration functions [35]. The alkaline $\mathrm{pH}$ also ensures anti-microbial activity [27]. Subsequent calcification of this superficial necrotic layer followed by tertiary dentin formation from stimulated and differentiated dental pulp stem cells give rise to a protective dentin-bridge [36]. Calcium ions contribute to this protective dentin-bridge formation as they stimulate DPSC differentiation and increase the formation of mineralized matrix nodules $[37,38]$. Interestingly, TheraCal ${ }^{\circledR}$ has been shown to release less calcium ions compared to Biodentine ${ }^{\mathrm{TM}}$ and no calcium hydroxide formation was seen when studied by X-ray diffraction analysis. This may be due to the lack of moisture to allow proper hydration of the tricalcium silicate elements in TheraCal $^{\circledR}$, which explains the absence of calcium hydroxide formation [32].

Besides the release of these ions involved in dentinbridge formation, a "bioactive" surface is formed due to the nucleation of calcium phosphates and subsequent apatite formation, in a moist environment. This apatite layer is suggested to stimulate cell differentiation, tissue repair, osteo- genesis and cementogenesis [22]. Silicon ions are another element that may play a role in dentin-bridge formation. Their release has been known to stimulate young bone formation by stimulating osteoblasts [39]. In case of direct pulp capping, it is believed that the presence of silicon ions in CSC, such as Biodentine ${ }^{\mathrm{TM}}$, also promote mineralization. An ex vivo tooth culture model showed that after pulp capping with Biodentine $^{\mathrm{TM}}$, small CSC particles were entrapped in the mineralized nodules which suggests that the material itself is involved in odontoblastic differentiation and mineralization $[17,18]$.

\section{Impact of direct pulp capping on the initial steps of inflammation}

Upon carious and/or physical injury of the dental-pulp, an inflammatory reaction is initiated in the remaining healthy pulp tissue [40]. While mild or moderate inflammation is required to stimulate the regenerative process, severe and/or chronic inflammation will be detrimental to the pulp. Significant advances in investigating the initial steps of inflammation using different cell culture and co-culture models in vitro clearly established that pulp fibroblasts play a major role in the initial steps of inflammatory process. Secreted proinflammatory cytokines such as Vascular Endothelial Growth Factor (VEGF), Interleukine 6 (IL-6) and Complement fragments such as $\mathrm{C} 3 \mathrm{a}$ and $\mathrm{C5a}$ induce vascular modifications to initiate inflammatory cell recruitment to the inflammation site [41-44]. These include adhesion of inflammatory cells to activated vascular endothelium, their migration through the endothelial cell layer and subsequent recruitment to the inflammation site where they are activated (Fig. 1).

In order to evaluate in vitro inflammatory mediators secreted in damaged and inflamed pulp tissue, pulp fibroblasts have been injured and/or stimulated with Gram positive lipoteichoic acid (LTA) and/or Gram negative lipopolysaccharide (LPS). Quantification of the pro-inflammatory released 
A

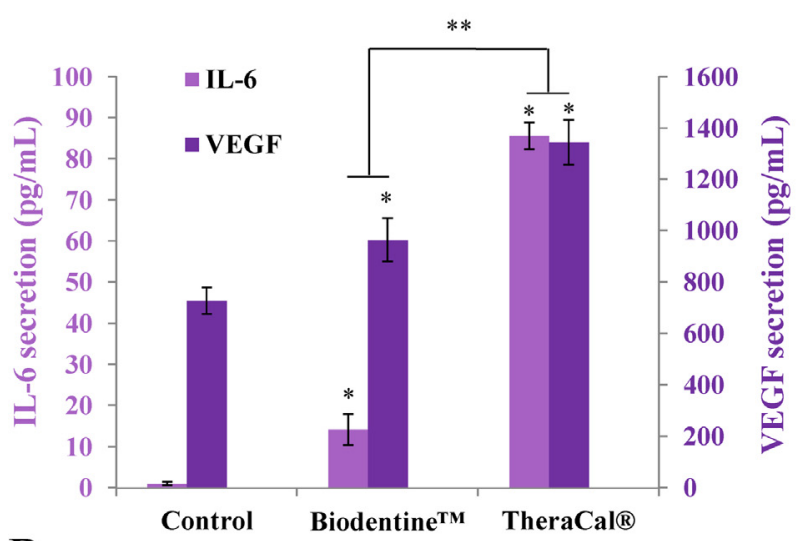

B

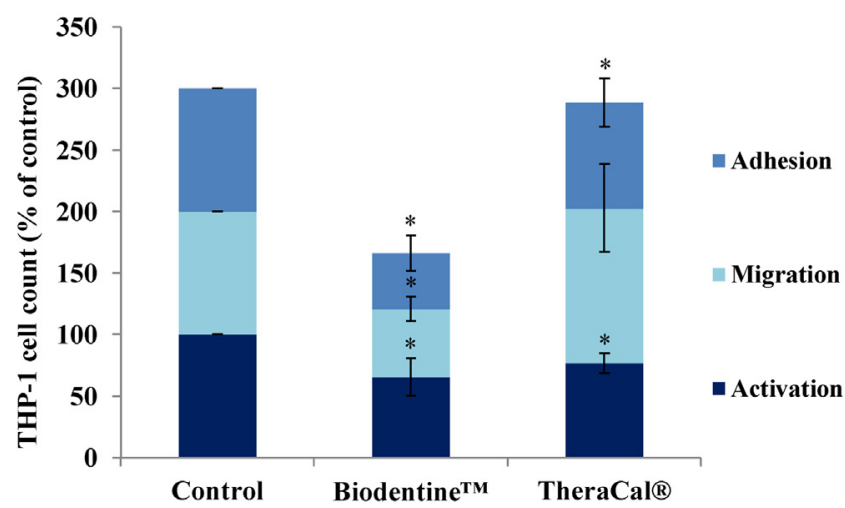

Fig. 4 - Pulp capping material effects on the initial steps of inflammation in vitro.

(A) Effects of materials on cytokine secretion. IL-6 and VEGF secretion by pulp fibroblasts significantly increased with both Biodentine ${ }^{\mathrm{TM}}$ and $\mathrm{TheraCal}^{\circledR}$ conditioned media after $48 \mathrm{~h}$ but to a lesser extent with Biodentine $\mathrm{T}^{\mathrm{TM}}$ as compared to the control as described [46]. (B) Effects of materials on inflammatory cell (THP-1) recruitment sequence. Biodentine $^{\mathrm{TM}}$ significantly decreases THP-1 adhesion to endothelial cells, migration and activation [46]. (*) corresponds to significant difference as compared to the control, $\left(^{* *}\right)$ represents significant differences between the two biomaterials ( $p$-value $<0.05$ ).

mediators showed that IL-6, IL-8, IL $1 \alpha$ and Tumor Necrosis Factor- $\alpha$ (TNF- $\alpha$ ) secretion increased in LPS-stimulated human DPSC [45]. Application of CSC has been shown to modulate pro-inflammatory mediator secretion. For instance, application of CSC extracts (TheraCal ${ }^{\circledR}$ and Biodentine ${ }^{\mathrm{TM}}$ ) on injured and LTA-stimulated pulp fibroblasts showed increased IL-6 and VEGF secretion (Fig. 4A), which was significantly higher for TheraCal ${ }^{\circledR}$ [46]. IL-8 secretion by pulp fibroblasts was also significantly higher with TheraCal ${ }^{\circledR}$ compared to Biodentine ${ }^{\mathrm{TM}}$ [18]. This modulation of IL-8 secretion by pulp capping materials is of interest as IL- 8 is a potent chemokine and plays a role in controlling the duration of the inflammatory process. MTA ${ }^{\circledR}$ has also been shown to increase IL-8 secretion by human neutrophils, the first inflammatory cells to reach the damaged site [47].
Investigating the effects of adding extracts of TheraCal ${ }^{\circledR}$ or Biodentine ${ }^{\mathrm{TM}}$ demonstrated that pulp capping materials modulate the inflammatory response. Inflammatory THP1 cells adhesion to endothelial cells and their activation were reduced by Biodentine ${ }^{\mathrm{TM}}$ and TheraCal ${ }^{\circledR}$. However, their migration decreased only with Biodentine ${ }^{\mathrm{TM}}$ [46] (Fig. 4B).

Given that severe pulp inflammation is detrimental to clinical outcome, pulp capping materials that reduce the inflammatory process are of particular interest. Several studies have shown favourable clinical outcome with materials such as MTA ${ }^{\circledR}$ and Biodentine ${ }^{\mathrm{TM}}$, which is most likely related to an attenuated inflammatory response. For instance, Kang et al. demonstrated that, after direct pulp capping for 8 weeks, a calcified dentin barrier was formed with ProRoot ${ }^{\circledR}$ MTA and Ortho ${ }^{\circledR}$ MTA whereas dentin barrier formation was incomplete with Endocem ${ }^{\circledR}$ MTA. The latter was associated with an inflammatory reaction [48]. Another study also suggests that mild inflammation is associated with thicker and more continuous dentine bridge formation. This was observed after 45 days for Biodentine ${ }^{\mathrm{TM}}$ as opposed to Dycal $^{\circledR}$ [49].

Various in vitro studies have provided insight in the underlying processes by which particular pulp capping materials shift the balance from inflammation towards regeneration. For instance, TNF- $\alpha$, an important pro-inflammatory cytokine released during pulp inflammation, has been shown to induce Transient Receptor Potential Ankyrin 1 (TRPA1) expression, which plays a role in nociception and neurogenic inflammation. Interestingly, Biodentine $\mathrm{TM}^{\mathrm{TM}}$ is able to attenuate this TNF- $\alpha$-induced TRPA1 expression and to reduce its functional activity [50].

\section{Pulp capping materials modulate the pulp regeneration potential}

In agreement with the above inflammation-reducing effect, Biodentine $^{\mathrm{TM}}$ is able to promote regenerative processes. For instance, Biodentine ${ }^{\mathrm{TM}}$ increases Transforming growth Factor $\beta 1$ (TGF- $\beta 1$ ) and Fibroblast Growth Factor 2 (FGF-2) secretion by injured pulp fibroblasts, as opposed to TheraCal ${ }^{\circledR}$ (Fig. 5A) [17]. TGF $\beta$-1 growth factor has been shown to stimulate odontoblastic differentiation [51] contributing as such to dentin-bridge formation. Recently, the interest of this growth factor release has been investigated by encapsulating these growth factors in PLGA microspheres allowing their gradual release. This in vivo study demonstrated that the gradual release of FGF-2 induces fibroblast and stem cell proliferation while TGF- $\beta 1$ guides DPSC recruitment [52], odontoblastic differentiation and tertiary dentin formation [53].

When the pulp injury was simulated in the scratch assay, an experimental model which simulates a physical tissue injury, pulp fibroblast migration to colonize the injury site was significantly higher with Biodentine ${ }^{\mathrm{TM}}$ than with TheraCal ${ }^{\circledR}$ [46] (Fig. 5B). Investigating DPSC migration in Boyden chamber also demonstrated a significantly higher migration of these cells in the presence of Biodentine ${ }^{\mathrm{TM}}$ as compared to TheraCal $^{\circledR}$ [54] (Fig. 5B).

These data clearly show that pulp capping materials also modulate the initial steps of pulp regeneration [46]. Moreover, while cell viability was maintained with Biodentine ${ }^{\mathrm{TM}}$, a sig- 
A

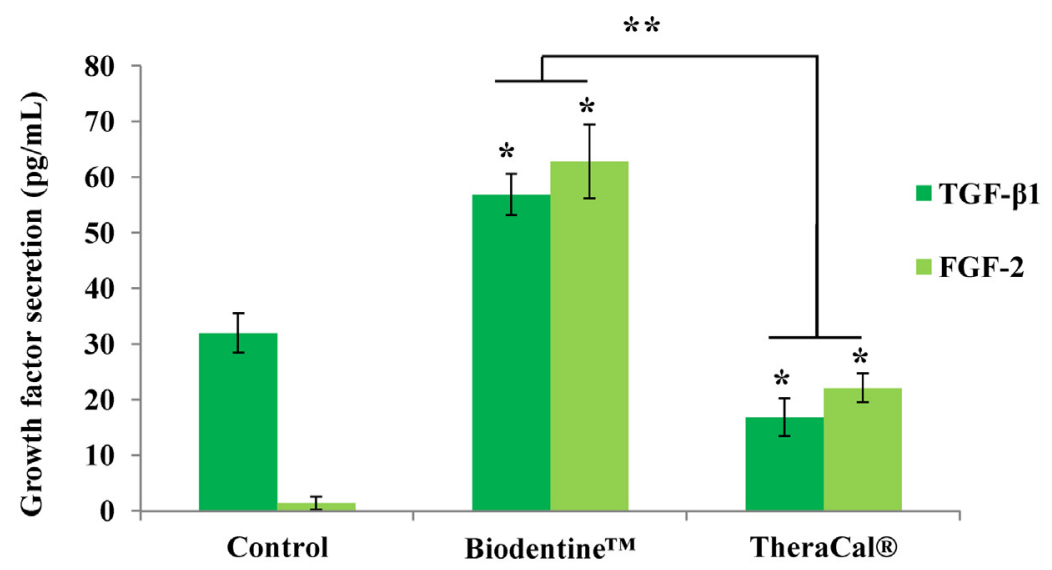

\section{Ba}

DPSCs migration
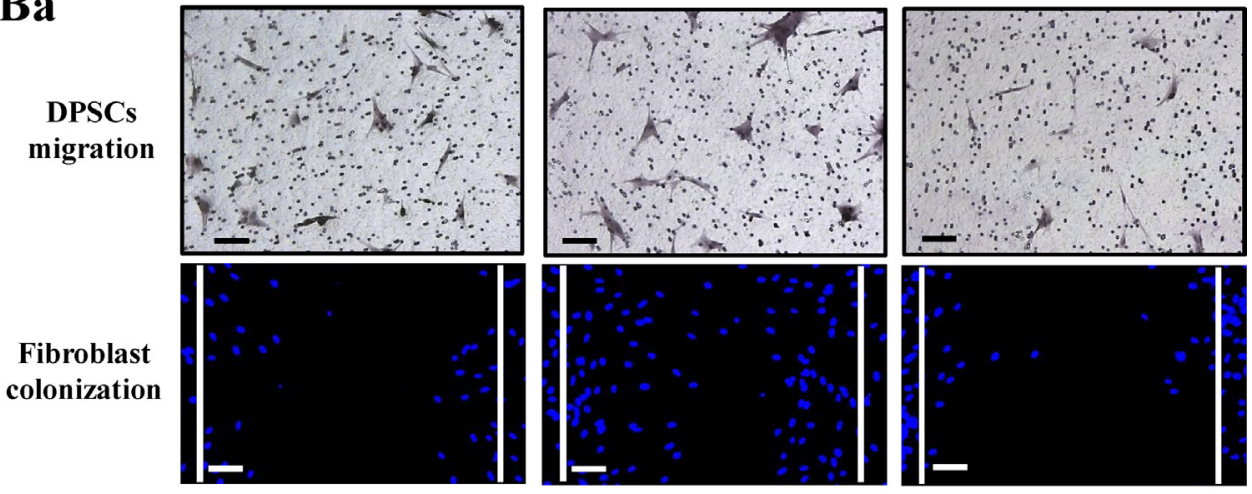

Control

Biodentine $^{\mathrm{TM}}$

TheraCal $^{\circledR}$

b

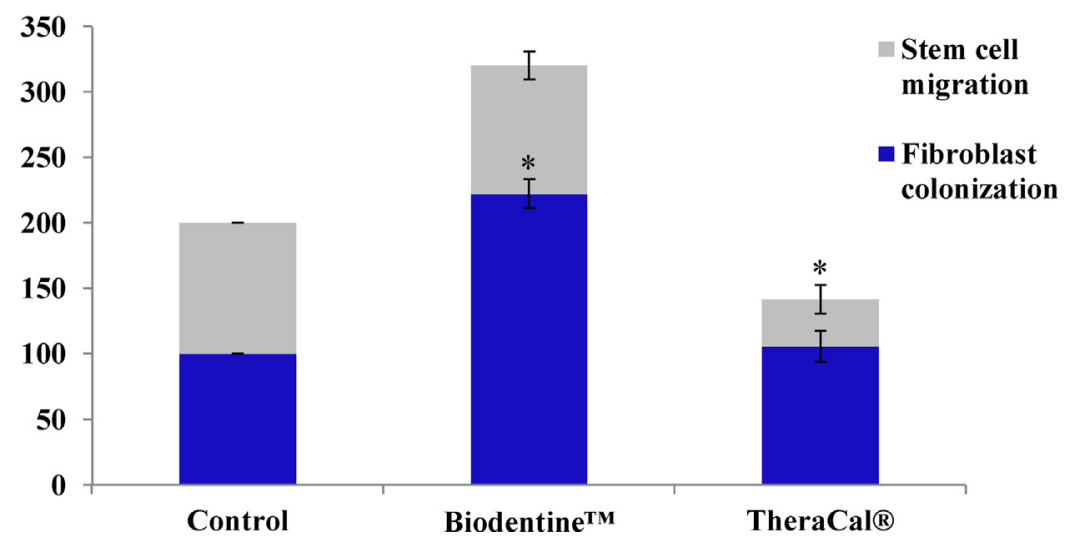

Fig. 5 - Pulp capping material effects on the initial steps of pulp regeneration in vitro.

(A) Effects of materials on growth factor secretion. Pulp fibroblasts secreted significantly more TGF- $\beta 1$ and FGF2 after $24 \mathrm{~h}$ of incubation with Biodentine ${ }^{\mathrm{TM}}$ than with TheraCal ${ }^{\circledR}$ as described [46]. (B) Effects of materials on stem cell migration and fibroblast colonization. (a) Representative pictures and (b) quantification of pulp fibroblasts scratch wound healing assay and DPSCs Boyden chamber migration assay with Biodentine ${ }^{\mathrm{TM}}$ and TheraCal $^{\circledR}$ as described $[46,54]$. Biodentine ${ }^{\mathrm{TM}}$ significantly induced fibroblast colonization while TheraCal ${ }^{\circledR}$ significantly decreased DPSCs migration. $\left(^{*}\right)$ corresponds to significant difference as compared to the control, $\left(^{* *}\right)$ represents significant differences between the two biomaterials $(p$-value $<0.05)$. Scale bars: $200 \mu \mathrm{m}$ for scratch wound healing assays and $\mathbf{5 0} \mu \mathrm{m}$ for Boyden chamber assays.

nificant decrease in pulp cell proliferation was reported with TheraCal $^{\circledR}$ (Fig. 6A). Investigating the pulp cell differentiation potential with the materials demonstrated a higher expression of odontoblastic markers such as Nestin and DSP with Biodentine $^{\mathrm{TM}}$ than with TheraCal ${ }^{\circledR}$ (Fig. 6B). When applied as direct pulp capping material in entire human tooth cultures, a significant number of mineralized foci was seen under Biodentine ${ }^{\mathrm{TM}}$ in an intact pulp tissue while a disorganized pulp tissue was observed under TheraCal ${ }^{\circledR}$ with small and a dispersed mineralization (Fig. 6C) [18]. This result was 

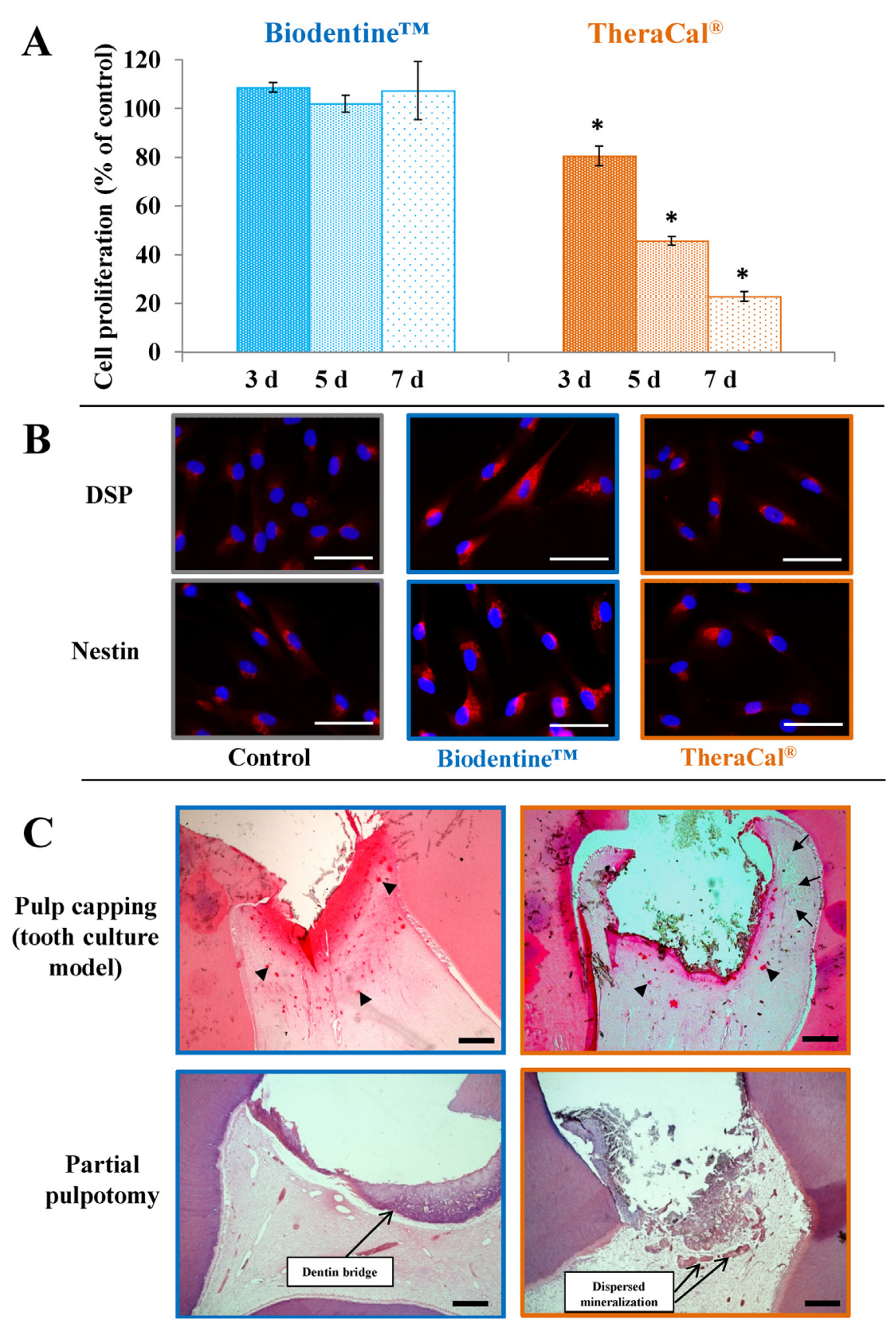

Fig. 6 - Effects of silicate-based pulp capping materials on pulp cell proliferation and pulp mineralization in vitro and in vivo. (A) Effect of Biodentine ${ }^{\mathrm{TM}}$ and TheraCal ${ }^{\circledR}$ on human pulp fibroblast proliferation [18]. A significant decrease in pulp fibroblast proliferation was observed with TheraCal ${ }^{\circledR}$ conditioned media for all incubation periods. ( $\left.{ }^{*}\right)$ corresponds to significant difference as compared to the control medium ( $p$-value $<0.05$ ). (B) Effect of the capping biomaterials on DSP and Nestin expression by DPSCs as described [18]. An increase of both markers was observed by immunofluorescence when DPSCs were cultured in contact with Biodentine ${ }^{\mathrm{TM}}$. Scale bars: $50 \mu \mathrm{m}$. (C) Histology results after direct pulp capping in vitro using the human tooth culture model (15 days) as described [18] and in vivo after tooth extraction (8 weeks) as described [55] with Biodentine ${ }^{\mathrm{TM}}$ and TheraCal ${ }^{\circledR}$. Entire tooth culture histology showed a higher mineralization with Biodentine ${ }^{\mathrm{TM}}$ while significant tissue disorganization was observed with TheraCal ${ }^{\circledR}$. After partial pulpotomy in human teeth a complete dentin bridge formed with Biodentine ${ }^{\mathrm{TM}}$ while only dispersed mineralizations in a disorganized pulp tissue were observed with $\mathrm{TheraCal}^{\circledR}$. Arrowheads indicate mineralization foci and arrows indicate pulp tissue disorganization. Scale bars: $500 \mu \mathrm{m}$. 


\begin{tabular}{|c|c|c|c|}
\hline & & \multicolumn{2}{|c|}{ Silicate-based materials } \\
\hline & & $\begin{array}{c}\text { Without resins } \\
\text { (Biodentine }^{\mathrm{TM}}, \mathrm{MTA}^{\circledR} \text { ) }\end{array}$ & $\begin{array}{l}\text { With resins } \\
\left(\text { (TheraCal }^{\mathbb{R}} \text { ) }\right.\end{array}$ \\
\hline \multirow{4}{*}{ In vitro } & $\begin{array}{l}\text { Hydration } \\
\text { byproducts }\end{array}$ & $\begin{array}{c}\mathrm{Ca}(\mathrm{OH})_{2}[31,34] \\
\text { Increased } \mathrm{Ca}^{+2} \text { release }[31,34] \\
\mathrm{OH}^{-}[30]\end{array}$ & $\begin{array}{c}\text { Absence of } \mathrm{Ca}(\mathrm{OH})_{2}[31,34] \\
\text { Less } \mathrm{Ca}^{+2}[31,34] \\
\mathrm{OH}^{-} \text {(not reported) }\end{array}$ \\
\hline & $\begin{array}{l}\text { Toxicity to } \\
\text { pulp cells }\end{array}$ & Non toxic $[18]$ & Toxic $[18,57]$ \\
\hline & $\begin{array}{c}\text { Inflammatory } \\
\text { effects }\end{array}$ & $\begin{array}{l}\text { Decrease immune cell recruitment [42] } \\
\text { Decrease pain receptor expression and } \\
\text { functional activity [47] }\end{array}$ & $\begin{array}{c}\text { Increase pro-inflammatory cytokine } \\
\text { secretion }[18,42]\end{array}$ \\
\hline & $\begin{array}{c}\text { Effect on pulp } \\
\text { organization }\end{array}$ & Intact pulp with mineralized foci [18] & Disorganized pulp tissue [18] \\
\hline \multirow[t]{2}{*}{ In vivo } & $\begin{array}{c}\text { Pulp } \\
\text { organization }\end{array}$ & $\begin{array}{l}\text { Intact with normal morphology } \\
\qquad[51,54,55]\end{array}$ & Disorganized [51] \\
\hline & $\begin{array}{c}\text { Pulp } \\
\text { mineralization }\end{array}$ & Presence of dentin bridge $[51,54,55]$ & Dispersed mineralization [51] \\
\hline
\end{tabular}

Fig. 7 - Biological effects of silicate-based materials on the dental pulp.

confirmed on partial pulpotomies in human third molars. Indeed, while a complete bridge under Biodentine ${ }^{\mathrm{TM}}$ formed in an intact pulp after 8 weeks, only a dispersed mineralization in a disorganized pulp was observed under TheraCal ${ }^{\circledR}$ (Fig. 6C) [55].

\section{Pulp capping materials outcome in vivo}

Clinical success of pulp capping procedures involves many aspects and is difficult to mimic in vitro. In vivo and clinical studies are thus an essential research part to evaluate not only dentin-pulp regeneration, but also inflammation and overall pulp response. CSC such as Biodentine ${ }^{\mathrm{TM}}$ and MTA $^{\circledR}$ showed good clinical outcomes with high success rates whereas TheraCal ${ }^{\circledR}$ was less successful. For instance, a clinical trial on pulpotomy in primary teeth showed a high rate of clinical and radiographic success for $\mathrm{MTA}^{\circledR}$ and Biodentine ${ }^{\mathrm{TM}}$ after 12 months (92\% and 97\%, respectively) [56]. Another study in permanent teeth also showed favourable outcomes for pulp capping with Biodentine $\mathrm{TM}^{\mathrm{TM}}$ and MTA ${ }^{\circledR}$. Their histological analysis showed that the majority of teeth had complete dentinal bridge formation and no inflammation after 6 weeks with both Biodentine $^{\mathrm{TM}}$ and MTA ${ }^{\circledR}$ [57]. A similar study compared pulp capping with calcium hydroxide, $\mathrm{MTA}^{\circledR}$, Biodentine ${ }^{\mathrm{TM}}$ and Single Bond Universal in human teeth. After 6 weeks, the dentin bridges formed in Biodentine ${ }^{\mathrm{TM}}$ group showed the highest average mineralization and maximum volumes while Single Bond Universal the lowest [58]. In dog partial pulpotomy, it was observed that TheraCal ${ }^{\circledR}$ capping led to extensive inflammation and incomplete calcified barrier formation. On the other hand, complete dentin-bridge formation with no inflammation was observed with ProRoot ${ }^{\circledR}$ MTA [59]. A clinical trial in adults showed complete dentin-bridge formation in all Biodentine ${ }^{\mathrm{TM}}$ cases whereas this rate was only $11 \%$ and $56 \%$ in TheraCal $^{\circledR}$ and ProRoot ${ }^{\circledR}$ MTA groups. In the TheraCal ${ }^{\circledR}$ group, two patients had severe pain and discomfort after one week [55]. This can be explained by the observed TheraCal ${ }^{\circledR}$ toxicity in in vitro studies [18,60]. Indeed, leaching of monomers due to incomplete hydration of $\mathrm{TheraCal}^{\circledR}$ leads to toxicity of the underlying pulp cells and induce as such an inflammatory response. This is particularly disadvantageous in the tooth confined environment where severe inflammation will lead to pain and subsequent clinical failure. It has also been shown that nontoxic concentrations of these monomers inhibit the secretion of dentin sialoproteins and osteonectin, which are involved in the mineralization process [61].

It is worth noting that recent data have demonstrated that using bioactive materials such as Biodentine ${ }^{\mathrm{TM}}$ and MTA ${ }^{\circledR}$ in partial or full pulpotomy to treat irreversible pulpitis leads to pulp function restoration and dentin bridge formation. This has been reported not only in immature but also in mature teeth [62-65]. These results, which represent a paradigm shift in irreversible pulpitis treatment, appear to be due to multiple factors:

1) The local regulation of pulp inflammation and regeneration [66]

2) The presence of stem cells and the inherent high pulp regeneration capacity $[51,67]$

3) The anti-inflammatory activity of bioactive materials such as Biodentine ${ }^{\mathrm{TM}}[46,50]$

4) The material byproducts on setting which induce stem cell differentiation and dentin bridge formation [28] 
5) The interaction of the material with the pulp fibroblast and subsequent release of factors such as FGF- 2 and TGF- $\beta 1$ involved in pulp tissue regeneration [52]

\section{Conclusions}

Overall, even if the initial inflammation is a pre-requisite for healing, a rapid resolution of inflammation would favour the regenerative process which is key for a successful clinical outcome [68]. Choosing an appropriate pulp capping material is crucial given that they can modulate the course of these events. It appears clearly that the presence of resins in CSC pulp capping materials such as TheraCal ${ }^{\circledR}$ shifts the balance towards inflammation. Their incomplete photopolymerization leads to free monomers release. When these monomers reach the underlying pulp, they exert their toxicity as demonstrated by decreased cell viability, release of pro-inflammatory cytokines and recruitment of inflammatory cells. It can be assumed that this creates an inflammatory state which compromises the regenerative process.

In addition, the incomplete $\mathrm{TheraCal}^{\circledR}$ hydration due to the presence of a high percentage of resin, leads to a reduced Calcium ion release and the absence of $\mathrm{Ca}(\mathrm{OH})_{2}$, both of which are known for their positive impact on the mineralization process (Fig. 7). Thus, pulp capping with TheraCal ${ }^{\circledR}$ can be held responsible for a disorganized pulp tissue without dentin bridge formation $[18,55]$. Based on these scientific findings, it can be concluded that even combined with Calcium silicates, resin-containing materials are not compatible with the spirit of direct pulp capping.

On the opposite, CSC pulp capping materials such as Biodentine $^{\mathrm{TM}}$ and $\mathrm{MTA}^{\circledR}$ shift the balance towards regeneration. Indeed, recent investigations demonstrated that Biodentine $\mathrm{T}^{\mathrm{TM}}$ has an anti-inflammatory activity by controlling pro-inflammatory factors secretion and decreasing inflammatory cells recruitment [46]. At the same time, the material hydration is complete leading to the formation/release of byproducts which shifts the pulp response towards regeneration as demonstrated through increased expression of factors involved in the regeneration process such as FGF-2 and TGF$\beta 1$, and the induction of dentin bridge formation while keeping an intact pulp (Fig. 7).

\section{Perspectives}

Current knowledge of pulp anti-inflammatory and regeneration potential would pave the way for development of future therapeutic agents that can target not only the regeneration but at the same time the pulp inflammation. Indeed, both inflammation and regeneration are required for a successful clinical outcome within the pulp inextensible environment. The fact that tissue lysis and destruction may result from a severe inflammation suggests that, beyond the pulp, this will also set the basis for development of bioactive materials in the treatment of other tissues located in a terminal circulation.

\section{Conflict of Interest}

Pr. Imad ABOUT reports financial support of research from Septodont during the development of Biodentine ${ }^{\mathrm{TM}}$.

\section{Acknowledgments}

The original works reported in this paper were supported by Aix-Marseille University and CNRS.

\section{RE F E R E N C E S}

[1] Goldberg M, Njeh A, Uzunoglu E. Is pulp inflammation a prerequisite for pulp healing and regeneration? Mediators Inflammation 2015;2015:347649.

[2] Cooper PR, Holder MJ, Smith AJ. Inflammation and regeneration in the dentin-pulp complex: a double-edged sword. J Endod 2014;40:S46-51.

[3] da Rosa WLO, Piva E, da Silva AF. Disclosing the physiology of pulp tissue for vital pulp therapy. Int Endod J 2018;51:829-46.

[4] Lawrence T. The nuclear factor NF-кB pathway in inflammation. Cold Spring Harb Perspect Biol 2009;1, a001651.

[5] Ley K, Laudanna C, Cybulsky MI, Nourshargh S. Getting to the site of inflammation: the leukocyte adhesion cascade updated. Nat Rev Immunol 2007;7:678-89.

[6] Murphy K, Travers P, Walport M, Janeway C. Janeway's immunobiology. 8th ed. New York: Garland Science; 2012.

[7] Chmilewsky F, Jeanneau C, Laurent P, About I. Pulp fibroblasts synthesize functional complement proteins involved in initiating dentin-pulp regeneration. Am J Pathol 2014;184:1991-2000

[8] Ehrengruber MU, Geiser T, Deranleau DA. Activation of human neutrophils by C3a and C5A Comparison of the effects on shape changes, chemotaxis, secretion, and respiratory burst. FEBS Lett 1994;346:181-4.

[9] Hartmann K, Henz BM, Krüger-Krasagakes S, Köhl J, Burger R, Guhl S, et al. C3a and C5a stimulate chemotaxis of human mast cells. Blood 1997;89:2863-70.

[10] Nataf S, Davoust N, Ames RS, Barnum SR. Human T cells express the C5a receptor and are chemoattracted to C5a. J Immunol Baltim Md 1999;1950(162):4018-23.

[11] Ricklin D, Hajishengallis G, Yang K, Lambris JD. Complement: a key system for immune surveillance and homeostasis. Nat Immunol 2010;11:785-97.

[12] Tomlinson S. Complement defense mechanisms. Curr Opin Immunol 1993;5:83-9.

[13] Jeanneau C, Rufas P, Rombouts C, Giraud T, Dejou J, About I. Can pulp fibroblasts kill cariogenic bacteria? Role of complement activation. J Dent Res 2015;94:1765-72.

[14] Huang GT-J, Gronthos S, Shi S. Mesenchymal stem cells derived from dental tissues vs. those from other sources. J Dent Res 2009;88:792-806.

[15] Miura M, Gronthos S, Zhao M, Lu B, Fisher LW, Robey PG, et al. SHED: stem cells from human exfoliated deciduous teeth. Proc Natl Acad Sci U S A 2003;100:5807-12.

[16] Sonoyama W, Liu Y, Fang D, Yamaza T, Seo B-M, Zhang C, et al. Mesenchymal stem cell-mediated functional tooth regeneration in swine. Plos One 2006;1:e79.

[17] Laurent P, Camps J, About I. Biodentine(TM) induces TGF- $\beta 1$ release from human pulp cells and early dental pulp mineralization. Int Endod J 2012;45:439-48. 
[18] Jeanneau C, Laurent P, Rombouts C, Giraud T, About I. Light-cured tricalcium silicate toxicity to the dental pulp. J Endod 2017;43:2074-80.

[19] Chmilewsky F, Jeanneau C, Laurent P, Kirschfink M, About I. Pulp progenitor cell recruitment is selectively guided by a C5a gradient. J Dent Res 2013;92:532-9.

[20] Rufas P, Jeanneau C, Rombouts C, Laurent P, About I. Complement C3a mobilizes dental pulp stem cells and specifically guides pulp fibroblast recruitment. J Endod 2016;42:1377-84.

[21] Chmilewsky F, Jeanneau C, Dejou J, About I. Sources of dentin-pulp regeneration signals and their modulation by the local microenvironment. J Endod 2014;40:S19-25.

[22] Prati C, Gandolfi MG. Calcium silicate bioactive cements: biological perspectives and clinical applications. Dent Mater Off Publ Acad Dent Mater 2015;31:351-70.

[23] Camilleri J, Montesin FE, Brady K, Sweeney R, Curtis RV, Ford TRP. The constitution of mineral trioxide aggregate. Dent Mater Off Publ Acad Dent Mater 2005;21:297-303.

[24] Dawood AE, Parashos P, Wong RHK, Reynolds EC, Manton DJ. Calcium silicate-based cements: composition, properties, and clinical applications. J Investig Clin Dent 2017;8:12195.

[25] Vallés M, Mercadé M, Duran-Sindreu F, Bourdelande JL, Roig M. Color stability of white mineral trioxide aggregate. Clin Oral Investig 2013;17:1155-9.

[26] Vallés M, Roig M, Duran-Sindreu F, Martínez S, Mercadé M. Color stability of teeth restored with biodentine: a 6-month in vitro study. J Endod 2015;41:1157-60.

[27] Torabinejad M, Hong CU, McDonald F, Pitt Ford TR. Physical and chemical properties of a new root-end filling material. J Endod 1995;21:349-53.

[28] About I. Recent Trends in Tricalcium Silicates for Vital Pulp Therapy. Curr Oral Health Rep 2018;5:178-85.

[29] About I. Cytotoxicity: mechanisms and in vivo studies. In: Biocompatibility or cytotoxic effects of dental composites. Oxford, UK: Coxmoor Publishing Company; 2009. p. 91-110.

[30] Camilleri J, Sorrentino F, Damidot D. Investigation of the hydration and bioactivity of radiopacified tricalcium silicate cement, Biodentine and MTA Angelus. Dent Mater Off Publ Acad Dent Mater 2013;29:580-93.

[31] Natale LC, Rodrigues MC, Xavier TA, Simões A, de Souza DN, Braga RR. Ion release and mechanical properties of calcium silicate and calcium hydroxide materials used for pulp capping. Int Endod J 2015;48:89-94.

[32] Camilleri J. Hydration characteristics of biodentine and theracal used as pulp capping materials. Dent Mater Off Publ Acad Dent Mater 2014;30:709-15.

[33] Aeinehchi M, Eslami B, Ghanbariha M, Saffar AS. Mineral trioxide aggregate (MTA) and calcium hydroxide as pulp-capping agents in human teeth: a preliminary report. Int Endod J 2003;36:225-35.

[34] Téclès O, Laurent P, Aubut V, About I. Human tooth culture: a study model for reparative dentinogenesis and direct pulp capping materials biocompatibility. J Biomed Mater Res B Appl Biomater 2008;85:180-7.

[35] Schröder U. Effects of calcium hydroxide-containing pulp-capping agents on pulp cell migration, proliferation, and differentiation. J Dent Res 1985;64:541-8.

[36] Schröder U, Sundström B. Transmission electron microscopy of tissue changes following experimental pulpotomy of intact human teeth and capping with calcium hydroxide. Odontol Revy 1974;25:57-68.

[37] Camilleri J, Laurent P, About I. Hydration of biodentine, theracal LC, and a prototype tricalcium silicate-based dentin replacement material after pulp capping in entire tooth cultures. J Endod 2014;40:1846-54.

[38] An S, Gao Y, Ling J, Wei X, Xiao Y. Calcium ions promote osteogenic differentiation and mineralization of human dental pulp cells: implications for pulp capping materials. J Mater Sci Mater Med 2012;23:789-95.

[39] Bielby RC, Christodoulou IS, Pryce RS, Radford WJP, Hench LL, Polak JM. Time- and concentration-dependent effects of dissolution products of 58S sol-gel bioactive glass on proliferation and differentiation of murine and human osteoblasts. Tissue Eng 2004;10:1018-26.

[40] Massler M. Pulpal reactions to dental caries. Int Dent J 1967;17:441-60.

[41] Kim I, Moon SO, Kim SH, Kim HJ, Koh YS, Koh GY. Vascular endothelial growth factor expression of intercellular adhesion molecule 1 (ICAM-1), vascular cell adhesion molecule 1 (VCAM-1), and E-selectin through nuclear factor-kappa B activation in endothelial cells. J Biol Chem 2001;276:7614-20.

[42] Hippenstiel S, Krüll M, Ikemann A, Risau W, Clauss M, Suttorp N. VEGF induces hyperpermeability by a direct action on endothelial cells. Am J Physiol 1998;274:678-84.

[43] Heinrich PC, Castell JV, Andus T. Interleukin-6 and the acute phase response. Biochem J 1990;265:621-36.

[44] Guo R-F, Ward PA. Role of C5a in inflammatory responses. Annu Rev Immunol 2005;23:821-52.

[45] Bindal P, Ramasamy TS, Kasim NHA, Gnanasegaran N, Chai WL. Immune responses of human dental pulp stem cells in lipopolysaccharide-induced microenvironment. Cell Biol Int 2018;42:832-40.

[46] Giraud T, Jeanneau C, Bergmann M, Laurent P, About I. Tricalcium silicate capping materials modulate pulp healing and inflammatory activity in vitro. J Endod 2018, http://dx.doi.org/10.1016/j.joen.2018.06.009, 0.

[47] Cavalcanti BN, Rode de SM, França CM, Marques MM. Pulp capping materials exert an effect on the secretion of IL-1 $\beta$ and IL- 8 by migrating human neutrophils. Braz Oral Res 2011;25:13-8.

[48] Kang C-M, Hwang J, Song JS, Lee J-H, Choi H-J, Shin Y. Effects of three calcium silicate cements on inflammatory response and mineralization-inducing potentials in a dog pulpotomy model. Mater Basel Switz 2018;11, http://dx.doi.org/10.3390/ma11060899.

[49] Jalan AL, Warhadpande MM, Dakshindas DM. A comparison of human dental pulp response to calcium hydroxide and biodentine as direct pulp-capping agents. J Conserv Dent JCD 2017;20:129-33.

[50] El Karim IA, McCrudden MTC, McGahon MK, Curtis TM, Jeanneau C, Giraud T, et al. Biodentine reduces tumor necrosis factor alpha-induced trpa1 expression in odontoblastlike cells. J Endod 2016;42:589-95.

[51] About I. Dentin-pulp regeneration: the primordial role of the microenvironment and its modification by traumatic injuries and bioactive materials. Endod Top 2013:28, http://dx.doi.org/10.1111/etp.12038.

[52] Mathieu S, Jeanneau C, Sheibat-Othman N, Kalaji N, Fessi H About I. Usefulness of controlled release of growth factors in investigating the early events of dentin-pulp regeneration. J Endod 2013;39:228-35.

[53] Zhang W, Walboomers XF, Jansen JA. The formation of tertiary dentin after pulp capping with a calcium phosphate cement, loaded with PLGA microparticles containing TGF-beta1. J Biomed Mater Res A 2008;85:439-44.

[54] Giraud T, Rufas P, Chmilewsky F, Rombouts C, Dejou J, Jeanneau C, et al. Complement activation by pulp capping materials plays a significant role in both inflammatory and pulp stem cells' recruitment. J Endod 2017;43:1104-10.

[55] Bakhtiar H, Nekoofar MH, Aminishakib P, Abedi F, Naghi Moosavi F, Esnaashari E, et al. Human pulp responses to partial pulpotomy treatment with theracal as compared with biodentine and ProRoot MTA: a clinical trial. J Endod 2017;43:1786-91. 
[56] Cuadros-Fernández C, Lorente Rodríguez AI, Sáez-Martínez S, García-Binimelis J, About I, Mercadé M. Short-term treatment outcome of pulpotomies in primary molars using mineral trioxide aggregate and Biodentine: a randomized clinical trial. Clin Oral Investig 2016;20:1639-45.

[57] Nowicka A, Lipski M, Parafiniuk M, Sporniak-Tutak K, Lichota D, Kosierkiewicz A, et al. Response of human dental pulp capped with biodentine and mineral trioxide aggregate. J Endod 2013;39:743-7.

[58] Nowicka A, Wilk G, Lipski M, Kołecki J, Buczkowska-Radlińska J. Tomographic evaluation of reparative dentin formation after direct pulp capping with $\mathrm{Ca}(\mathrm{OH})_{2}$, mta, biodentine, and dentin bonding system in human teeth. J Endod 2015;41:1234-40.

[59] Lee H, Shin Y, Kim S-O, Lee H-S, Choi H-J, Song JS. Comparative study of pulpal responses to pulpotomy with ProRoot MTA, RetroMTA, and TheraCal in Dogs' teeth. J Endod 2015;41:1317-24.

[60] Hebling J, Lessa FCR, Nogueira I, Carvalho RM, Costa CAS. Cytotoxicity of resin-based light-cured liners. Am J Dent 2009;22:137-42.

[61] Diamanti E, Mathieu S, Jeanneau C, Kitraki E, Panopoulos P, Spyrou G, et al. Endoplasmic reticulum stress and mineralization inhibition mechanism by the resinous monomer HEMA. Int Endod J 2013;46:160-8.
[62] Taha NA, Abdelkhader SZ. Outcome of full pulpotomy using Biodentine in adult patients with symptoms indicative of irreversible pulpitis. Int Endod J 2018;51:819-28.

[63] Taha NA, Abdulkhader SZ. Full pulpotomy with biodentine in symptomatic young permanent teeth with carious exposure. J Endod 2018;44:932-7.

[64] Taha NA, Khazali MA. Partial pulpotomy in mature permanent teeth with clinical signs indicative of irreversible pulpitis: a randomized clinical trial. J Endod 2017;43:1417-21.

[65] Asgary S, Eghbal MJ, Bagheban AA. Long-term outcomes of pulpotomy in permanent teeth with irreversible pulpitis: A multi-center randomized controlled trial. Am J Dent 2017;30:151-5.

[66] Jeanneau C, Lundy FT, El Karim IA, About I. Potential therapeutic strategy of targeting pulp fibroblasts in dentin-pulp regeneration. J Endod 2017;43:S17-24

[67] Nakashima M, Iohara K. Regeneration of dental pulp by stem cells. Adv Dent Res 2011;23:313-9.

[68] Farges J-C, Alliot-Licht B, Renard E, Ducret M, Gaudin A Smith AJ, et al. Dental pulp defence and repair mechanisms in dental caries. Mediators Inflamm 2015;2015:230251. 